ECONOMICS

Tasnuba Haque,

Universiti Kebangsaan Malaysia

(UKM), Malaysia

E-mail: tasnubaist@@yahoo.com

Chamhuri Siwar,

Universiti Kebangsaan Malaysia

(UKM), Malaysia

E-mail:csiwar@ukm.my

Abul Bashar Bhuiyan,
University Selangor (Unisel),
Shah Alam, Malaysia
E-mail: bashariuk@gmail.com

Mohd Hasanur Raihan

Joarder,

United International University

(UIU)

E-mail:

raiban.joarder@bus.uiu.ac.bd

Received: January, 2019

1st Revision: April, 2019

Accepted: December, 2019

DOI: $10.14254 / 2071-$

789X.2019/12-4/15

JEL Classification: D02, O17, P31
Haque, T., Siwar, C., Bhuiyan, A.B., \& Joarder, M.H.R. (2019). Contributions of Amanah Ikhtiar Malaysia (AIM) microfinance to Economic Empowerment (EE) of women borrowers in Malaysia. Economics and Sociology, 12(4), 241-256. doi:10.14254/2071-789X.2019/12-4/15

\section{CONTRIBUTIONS OF AMANAH IKHTIAR MALAYSIA (AIM) MICROFINANCE TO ECONOMIC EMPOWERMENT (EE) OF WOMEN BORROWERS IN MALAYSIA}

\begin{abstract}
The main aim of the study is to investigate the impact of AIM micro-crediting on the on the Economic empowerment (EE) of the borrowers at the East Coast Region in Malaysia. The study used both the quantitative and qualitative approach based on primary data from the field. There are 384 samples of AIM's borrowers were collected from the Terengganu, Kelantan, and Pahang in East Coast Economic Region (ECER), Malaysia. The present study has used descriptive statistical and women empowerment index. The women empowerment index (the Economic Empowerment Index) employed to measure the level development of the status of women in economical decisionmaking contexts. The study summarized that AIM's credit has contributed towards the 'improvement of empowerment of women in all categories of Economic issues. The present study recommends policy considerations for the successful and effective operation of microfinance programs through the increase of proper income generating activities, sufficient amount of access to credit, create self-employment opportunity in Malaysia.
\end{abstract}

Keywords: Microfinance, Microcredit, Economic Empowerment (EE), Amanah Ikhtiar Malaysia (AIM), Malaysia.

\title{
Introduction
}

Microfinance means provision of access to small amounts of credit to the poor and those who do not have assets for collateral, financial records, and credit history. Microfinance can be used for IGAs to alleviate poverty and ensure livelihood development. Women comprise 95\% 
of all borrowers of MFIs. At the same time, poor women are often ignored in most parts of the society (Basher, 2007). They are marginalized and have no opportunities for self-sufficiency, and thus, become dependent on charity or welfare (A.B. Bhuiyan, Siwar, Ismail, \& Hossain, 2012). Hence, poor women lose their self-confidence because they cannot be fully selfsupporting. Denied opportunities deprive poor women of the pride of accomplishment. This situation, in turn, leads to psychological, social, and mental health problems (Vargas \& Maria, 2002).

Women empowerment is a means to achieve basic opportunities for poor women. Empowerment includes encouraging and developing skills for self-sufficiency, with a focus on eliminating the need for charity or welfare support (Gibbons \& Kasim, 1990; Salma, 2004; Nawai \& Bashir, 2009). In spite of remarkable economic growth in Malaysia which is reducing inter-ethnic income disparity and economic imbalance, hard-core poverty and problems with women empowerment are the prime threats that hinder Malaysia from being declared as a completely developed country by 2020 (Mamun, Wahab, Hossain, \& Malarvizhi, 2011). The Amanah Ikhtiar Malaysia (AIM) has been the major and largest MFI in Malaysia (Salma, 2004; Mamun et al., 2011). By adopting the Grameen Bank microcredit approach, AIM provides poor women with access to credit for IGAs and eventually move them out of poverty.

Analysis of the existing literature reveals there are limited studies on the assessment of AIM microcredit performance in part of success stories about women empowerment in Malaysia. Thus, this study will analyze the contribution of AIM to improving economic empowerment of poor women borrowers in Malaysia. This research will also propose future directions for the effective use of credit for IGAs and development of poor women in Malaysia.

\section{Literature review}

\subsection{Microfinance in Malaysia}

Malaysia is touted as an Asian miracle because of the remarkable economic growth within the last three decades. Microcredit is a proven tool against poverty in developed and developing countries. It has launched a challenge to the formal financial system with the hope of development for the poor, who comprises a large part of the world population. Microfinance is not new in Malaysia. This program has been operated by credit unions, cooperative banks, and the specialized credit windows of banks. The formal microcredit institutions were developed in Malaysia when Majlis Amanah Rakyat (MARA) was formed by an act of parliament in 1966. It originally began as the Rural Industrial Development Authority (RIDA), which was a program that was established by the British colonial administration in 1951. RIDA aimed to provide economic assistance and to support Malay farmers and rural inhabitants. This organization was later expanded and became MARA in 1966. The council of trust to the Bumiputera and Credit Guarantee Corporation (CGC) introduced microfinance loans to its borrowers. Currently, several government and non-government organizations (NGOs), such as Yayasan Usaha Majuin Sabah, Koperasi Kredit Rakyat in Selangor, Tabung Ekonomi Kumpulan Usaha Neaga (TEKUN), Credit Guarantee Corporation (CGC), National Savings Bank (BSN), and AIM, engage in national and local microfinance in Malaysia. Moreover, a few remarkable institutions that have been providing microcredit in the agricultural sectors are the Agriculture Bank of Malaysia (BPM), Farmers Organization Authority (LPP), Federal Land Development Authority (FELDA), and agro-based Cooperative Societies. Very recently, several commercial banks, for example, CIMB, are also engaged in microcredit activities. However, these banks do not operate their activities directly as microfinance providers. Their 
involvement is limited to expanding the lines of credit to AIM and other MFIs as a mediator for the schemes (APEC, 2005). Some of the MFIs of the government and NGOs in Malaysia are described in Table 1.1.

Table 1.1. Active MFIs in Malaysia

\begin{tabular}{lccc}
\hline Name of MFIs & $\begin{array}{c}\text { Date of } \\
\text { Birth }\end{array}$ & Status & Locations/Scale \\
\hline Federal Land Authority (FELDA) & 1956 & Governmental & National \\
\hline Majlis Amanah Rakyat (MARA) & 1966 & NGO & National \\
\hline Credit Guarantee Corporation (CGC) & 1972 & Governmental & National \\
\hline Farmers Organization Authority (LPP) & 1973 & Governmental & National \\
\hline National Savings Bank (BSN) & 1974 & Governmental & National \\
\hline Amanah Ikhtiar Malaysia (AIM) & 1987 & NGO & National \\
\hline Koperasi Kredit Rakyat (KKR) & 1988 & NGO & Selangor \\
\hline $\begin{array}{l}\text { Tabung Ekonomi Kumpulan Usaha Negara } \\
\text { (TEKUN) }\end{array}$ & 1998 & NGO & National \\
\hline Yayasan Usaha Maju (YUM) & 2002 & NGO & Sabah \\
\hline Bank Pertanian Malaysia (BPM) & 2003 & Governmental & National \\
\hline
\end{tabular}

Sources: (APEC, 2005)

\subsection{Concept of empowerment and women empowerment}

The term empowerment comes from the word "empower," which means "to give power or authority to someone." Moreover, empowerment is an intrinsic quality of a person, which cannot be bestowed by a third party. The behavior of an empowered person is considered to change. Briefly, empowerment is a process that enables one to gain power, authority, and influence over others. Scholars have given their opinion on the concept of empowerment.

People assume "control and mastery over their lives in the context of their social and political environment." Some researchers describe empowerment as a continuous, on-going, and interactive process that leads to the enhancement of abilities and a wider scope for choice and action of an individual. Thus, empowerment leads to equity and well-being of the individual and the community (Wallerstein, 1992). Moreover, "the empowerment as a process of enabling or authorizing an individual to think, behave, and take action and controlling work autonomously. It involves some degree of personal development. Individuals become empowered when they obtain the right to determine choices in life and to influence the direction of change through the ability to gain control over material and non-material resources. The World Bank 'Empowerment Source Book' also defines empowerment in the same way" (Rowlands, 1997).

By contrast, women empowerment is an active and multi-dimensional, process, which enables women to realize their full identity and power in all spheres of life. Power is neither a commodity to be transacted nor alms that can, be given away. Power has to be acquired, and once acquired, power needs to be exercised, sustained, and preserved. There are a number of studies about the issues of women empowerment. Stromquist (1995) explains that empowerment includes both cognitive and psychological elements. It involves "women's understanding of their conditions of subordination and the causes of such conditions at both micro and macro levels of society. It involves understanding the self and the need to make choices that may go against cultural and social expectations" (Stromquist, 2002). Moreover, women empowerment is a process of improving the status and abilities of women to enable 
them to lead their lives autonomously. Women empowerment is a complicated and continuous process, which aims to change the way of thinking of the whole society to ensure the equal enjoyment of human rights for all. Women empowerment is a continuous process of increasing the economic, social, political, and psychological strengths (Rowlands, 1997; Stromquist, 2002; Wallerstein, 1992). Finally, the study summarizes the concept of women empowerment as a process that allows one to gain knowledge, power, skill-sets, and attitude that are needed to cope with the changing world and the circumstances in the environment in increasing the productivity of self, family, and the society as a whole.

\subsection{Microfinance and women empowerment}

Microfinance is considered the provision of access to small amounts of credit to the poor and those who do not have assets for collateral, financial records, and credit history. Microfinance can be used for IGAs to alleviate poverty and ensure livelihood development. The results lead to improving health, providing access to education to children, achieving skills, acquiring assets, and taking part in social activities. Women comprise $95 \%$ of the borrowers of MFIs, and thus, knowing how these poor women are being empowered through access to credit is important. The study will look into how the women have improved their lives by accessing and utilizing resources provided by the microfinance program. These activities include participation in the household decision-making, improving self-confidence and democratic institutions in the rural area, and increased awareness of the existing social, economic, and household environment.

\subsection{Empirical review}

As women comprise half of society, they have the right to move into the mainstream of development. Their ability to take advantage of opportunities to increase their income or economic status, to protect themselves against other risks, and to increase their ability to cope with risks when they occur is very important. The reduction of poverty is partly a process of increasing income and economic stability, which enables the fulfillment of basic needs and access to different kinds of services. Poverty reduction has come into the forefront with the revolution of microcredit when Yunus realized that women empowerment is an essential and a precondition, as well as with men, to remove poverty from the society. Studies revealed the extent to which microfinance has contributed to women's empowerment in controlling family decisions. For instance, microfinance of Grameen Bank allowed women borrowers to increase their involvement in controlling assets and social welfare (Zaman, 1999). However, the study of Abdullah-Al-Mamun et al. examined how the participation in the microcredit program of AIM affected the employment rate of hard-core poor households and community in Peninsular Malaysia in 2011. Participation in the microcredit program of AIM increased employment, which generated opportunities at the household and community levels. The policy may be reviewed and re-organized to increase the employment rate and income-generating opportunities by providing appropriate training and diversified, flexible loan offers (Mamun, et al., 2011). Moreover, another study explained how AIM achieved its social performance in terms of the outreach to the poor and excluded its adaptation of services and products to client needs, and the improvement of the social and political capital of the poor and its social responsibility (Siti-Nabiha \& Siti-Nazariah, 2011). There are few studies on the decisionmaking of women borrowers were concluded positively. Although women were more often regarded as housekeepers, they were later deemed as alternative sources of income as they have 
increased their status with their decision-making power for developing family welfare (S. R. Khandker \& Chowdbury, 1996).

While microcredit programs explored the promises and perils associated with the effect of microfinance on educational outcomes. The goal of this discussion is to ensure that the pervasiveness of microfinance across the world was accompanied by benefits to educational outcomes (Holland \& Wang, 2001). Another study also found large positive effects of participation and the non-credit aspects of participation on self-employment profits (McKernan, 2002). However, analyze showed that some women chose not to invest the money in trading and chose to recycle the cash through high-interest loans to other farmers, The study examined the institutional changes unraveling in rural areas of Senegal that contributed to the rise of a new class of female moneylenders during the contemporary epoch of neoliberal reform and offered the ethnographic descriptions of the money lending practices of women (Perry, 2002). Another empirical study examined the effect of group-based credit for the poor in Bangladesh and study revealed microcredit programs helped the borrowers whose income flow and time demand did not seasonally cover the income generated by existing agricultural activities. Households are selected into these programs during the lean season of consumption poverty, which showed the largest female and male effects of credit (Pitt, Khandker, Chowdhury, \& Millimet, 2003).

In the same way, explored the effect of a woman-focused development program on child survival in Matlab, a rural area in Bangladesh. The pre-intervention the hazard of death during the infancy of the children of participant mothers was reduced by $52 \%$, whereas that of nonparticipant mothers with a similar socioeconomic background was reduced only by $31 \%$. A substantial reduction in the hazard of death during childhood (1-4 year age group) was also noticed; however, the reduction was statistically similar for all the groups of children irrespective of the participation of their mothers in the development program (Bhuiya \& Chowdhury, 2002). Another study suggested that access to microfinance contributes to poverty reduction, especially for female participants, and overall poverty reduction at the village level. Thus, microfinance helps not only poor participants, but also the local economy (S. R. Khandker, 2005). However, another study showed how structural constraints and institutional discourses still rendered livelihood diversification gendered projects (Angeles \& Hill, 2009).

Ahmad revealed that enabling and improving the quality of education for women is necessary to increase their participation in marketing activities, where the gender disparity in earnings is less. Moreover, developing desirable social and institutional infrastructures enabled women to move outside the home to participate in economic and social activities and to reduce the burden of their domestic work (Bose, Ahmad, \& Hossain, 2009). Zahra et al. found that the social entrepreneurship is the subject of several studies. The study concluded by outlining implications for entrepreneurs and advancing an agenda for future research, especially on the ethics of social entrepreneurship (Zahra, Gedajlovic, Neubaum, \& Shulman, 2009). Moniruzzaman found there are effects of empowering inputs, such as microcredit, then the internal management of the group. The study examined the serious defects that may have direct negative effects on empowering outcomes. The study argued that paying greater attention to the internal management of the groups can make the group approach more effective in community development (Moniruzzaman, 2011). Moreover, Esnard-Flavius and Aziz (2011) examined the relationship between microcredit and fragmented social relations within the network, conflict, distrust, and the loose structure of the program limited the effects of access to microcredit on social welfare and the financial potential of the lending organization (EsnardFlavius \& Aziz, 2011).

Ahmed and Siwar found the relationship between microcredit, IGAs, awareness, and women empowerment, and highlighted a review of the existing evidence on the role of a 
microcredit program in developing socio-economic status and poverty alleviation(Ahmed, Siwar, \& Idris, 2011a). Ahmed and Siwar described that women, who constituted almost half of the total population of Bangladesh, are victims of socio-economic inequality and gender disparity. Women were also economically dependent, vulnerable, and socially discriminated. Their study focused on the status of women in Bangladesh. However, the government has taken many initiatives to ensure the political rights and to increase the awareness, empowerment, and participation of vulnerable and disadvantaged women (Ahmed, Siwar, \& Idris, 2011b). Besides, Ahmed and Siwar stated that rural women in Bangladesh are the most deprived in society, and most rural women are extremely poor. The study examined the extent of changes in the livelihood status of rural women through their involvement in microcredit programs in Bangladesh. The study revealed that after joining the microcredit program, the rural women engaged themselves in IGAs and, consequently, improved their livelihood status significantly (Ahmed, Siwar, Idris, \& Begum, 2011). Moreover, the monthly average income of the respondents with credit is US\$27.6, which is three times higher than that of the respondents without credit, which was US\$7.9. The increased income of the women borrowers contributed significantly in improving the income level of their households, and thus, , help them reduce vulnerability more effectively than the women who did not borrow (Ahmed, Siwar, Idris, \& Mia, 2011).

\section{Methodological approach}

The study used both quantitative and qualitative approach based on the primary data from the field. For this study, the participants comprised 384 AIM borrowers from Terengganu, Kelantan, and Pahang in east coast region of Malaysia. The study used descriptive statistical and WEI. This study used some inferential descriptive statistical tests, including the parametric tests of means (ANOVA and T-tests), and correlations. The WEI was employed to measure the level of development of the status of women in terms of Economic decision-making issues.

Hence, the study employed the WEI, which was constructed by D. Thresiamma Varghese in 2011 (Varghese, 2011). Women empowerment in the domestic sphere was measured by creating the WEI based on the dimensions according to Mason and Smith (2003). The particular aspects or dimensions of empowerment are the economic decision-making power of women (economic empowerment (EE), their household decision-making power (household empowerment (HE), and their physical freedom of movement (social empowerment (SE) (Mason \& Smith, 2003; Varghese, 2011).

The index of each dimension was constructed by choosing the minimum and maximum values for each underlying indicator. The performance in each indicator is expressed as the minimum and maximum value between 0 and 1 according to the construction method of the Human Development Index (UNDP, 2005). The WEI is then computed as the simple average of these three indexes according to the following formula:

where:

$$
\operatorname{IVij}=\frac{(X i j)-\operatorname{Min}(X i j)}{(X i j)-\operatorname{Max}(X i j)}
$$

$$
\begin{aligned}
& \text { IVij }=\text { index value } \\
& \text { Xij= actual value } \\
& \operatorname{Min}(X i j)=\text { minimum value } \\
& \operatorname{Max}(X i j)=\text { maximum value }
\end{aligned}
$$

In the Human Development Index of UNDP, a value of 0 is deprived of a development value of 1 , which shows full development, a value between 0 to 0.5 means a minimum level of 
development, 0.6 to 0.7 refers to the medium level of development, and 0.8 and higher means high development (UNDP, HDI, 2005). We took the same method of differentiating the human trait empowerment according to the index. The study framed the household, social, and economic empowerment and used these factors to obtain the total empowerment index. The study used the following indicators to measure the level of women empowerment.

* Economic Empowerment (EE)

- Decision on how to spend money

- Decision on large household purchases, like furniture and other items

- Decision on buying gifts for social functions

\section{Conducting research and results}

\subsection{Earning Members in the Household}

The total number of earning household members is an important factor in the increase in income of households. The total number of earning members is the number of family members who are employed or engaged in IGAs. The general assumption is the household income is higher if the number of earning members is higher, while other relevant factors remain constant. The present study used the total number of earning members as an important indicator to determine how the number of earning members influenced the total household income of microcredit borrowers.

Table 3.1 Earning Members in the Household

\begin{tabular}{lccccccc}
\hline \multicolumn{7}{c}{ Earning Members in the Household } \\
\hline Item & 2 & 3 & 4 & 5 & 6 & 7 & Total \\
\hline Frequency & 172 & 55 & 95 & 41 & 18 & 3 & 384 \\
\hline Percentage (\%) & 44.8 & 14.3 & 24.7 & 10.7 & 4.7 & 0.8 & 100 \\
\hline Mean & \multicolumn{7}{c}{3.42} \\
\hline Std. Deviation & \multicolumn{7}{c}{1.85} \\
\hline Minimum & \multicolumn{7}{c}{2} \\
\hline Maximum & \multicolumn{7}{c}{7} \\
\hline
\end{tabular}

Source: Primary Data from Survey

Table 3.1 reveals that $44.8 \%$ of families who are members of AIM have only two earning members. Only $14.3 \%$ of the families have three members engaged in IGAs, and, only $24.7 \%$ of the families have four earning members. Finally, $16.2 \%$ of families have five or more earning family members.

\subsection{Status of Employment of Respondents}

Table 3.2 shows the status of employment of respondents before and after joining AIM. Only $61.7 \%$ of the respondents were involved in self-employment or business before they joined AIM, and 23.4\% were housewives. After joining AIM, the members who engaged in self-employment increased to $77.6 \%$, whereas housewives comprised only $21.3 \%$ of the respondents. Therefore, the AIM credit has increased self-employment. 
Table 3.2. Status of Employment Before and After Joining AIM

\begin{tabular}{lcccc}
\hline \multirow{2}{*}{ Types of Business } & \multicolumn{4}{c}{ Types of Employment } \\
\cline { 2 - 5 } & \multicolumn{3}{c}{ Before } & \multicolumn{3}{c}{ After } \\
\cline { 2 - 5 } & Frequency & Percentage (\%) & Frequency & Percentage (\%) \\
\hline Housewife & 90 & 23.4 & 82 & 21.3 \\
\hline Business & 237 & 61.7 & 298 & 77.6 \\
\hline Others & 57 & 14.9 & 4 & 1 \\
\hline Total & 384 & 100 & 384 & 100 \\
\hline
\end{tabular}

Source: Primary Data from Survey

\subsection{Respondents involved in the microcredit scheme of AIM}

Table 3.3 shows that the involvement of the respondents in credit is 5.42 years on average. The maximum and minimum involvement range is 19 years and 1 year, respectively.

Table 3.3. Number of years involved in AIM

\begin{tabular}{lc}
\hline Number of Years Involved in AIM & \\
\hline Measurement Scale & Number of Years \\
\hline Mean & 5.42 \\
\hline Minimum & 1 \\
\hline Maximum & 19 \\
\hline
\end{tabular}

Source: Primary Data from Survey

\subsection{Ranges and Total Amount of Loan Received}

Table 3.4 presents the range and the total amount of loans received by respondents. Based on the survey, only about $7 \%$ of the respondents borrowed RM2000. Most respondents (28.4\%) borrowed RM2000 to 4000 . Table 4.8 also shows that $8.6 \%, 15.6 \%$, and $6.5 \%$ of the respondents borrowed RM4001 to 6000, RM6001 to 8000, and RM8001 to 10000, respectively.

Table 3.4. Range and total amount of loan received

\begin{tabular}{|c|c|c|}
\hline \multicolumn{3}{|c|}{ Range and Total Amount of Loan Received } \\
\hline Loan Ranges & Frequency & Percentage $(\%)$ \\
\hline$<$ RM2000 & 27 & 7 \\
\hline RM2000 to 4000 & 109 & 28.4 \\
\hline RM4001 to 6000 & 33 & 8.6 \\
\hline RM6001 to 8000 & 60 & 15.6 \\
\hline RM8001 to 10000 & 25 & 6.5 \\
\hline RM10001 to 15000 & 47 & 12.2 \\
\hline RM10001 to 20000 & 18 & 4.7 \\
\hline RM20001 to 25000 & 11 & 2.9 \\
\hline RM20001 to 50000 & 32 & 8.3 \\
\hline > RM 50000 & 22 & 5.7 \\
\hline Total & 384 & 100 \\
\hline Mean & \multicolumn{2}{|c|}{11541.67} \\
\hline Minimum & \multicolumn{2}{|c|}{2000} \\
\hline Maximum & \multicolumn{2}{|c|}{100000} \\
\hline
\end{tabular}

Source: Primary Data from Survey 
Furthermore, $12.2 \%, 4.7 \%, 2.9 \%$, and $8.3 \%$ of the respondents borrowed RM10001 to 15000, RM10001 to 20000, RM20001 to 25000, and RM20001 to 50000, respectively. The highest amount of loan is RM50000, which was lent to 5.7\% of the respondents. The average amount of loan is RM11541.67, while the maximum amount of loan is RM100000 and the minimum amount of loan is RM2000.

\subsection{Household income of respondents before and after joining AIM}

The total income of the household is based on what the respondents remember. The data from the survey showed that the average monthly household income of the respondents increased over the last five years.

Table 3.5. Household Income Before and After Joining AIM

\begin{tabular}{|c|c|c|}
\hline \multicolumn{3}{|c|}{ Distribution of Household Income } \\
\hline \multirow{2}{*}{ Measurement Scale } & \multicolumn{2}{|c|}{ Household Income } \\
\hline & Before & After \\
\hline Mean & 516.15 & 1765.86 \\
\hline Minimum & 200 & 300 \\
\hline Maximum & 3500 & 13500 \\
\hline Increase (\%) & \multicolumn{2}{|c|}{$242.12 \%$} \\
\hline
\end{tabular}

Source: Primary Data from Survey

Table 3.5 indicates that the average monthly income of the respondents is RM1765.86 at present and RM516.15 five years ago. Furthermore, the households of the respondents were able to increase their family income by $242.12 \%$ in five years.

\subsection{Range of income before and after joining AIM}

Table 3.6 shows the range of income of borrowers before and after joining AIM. Before joining AIM, the income of $11.2 \%$ of the respondents were around RM500. After joining AIM, only $7.3 \%$ of the respondents retained having an income of around RM500. Moreover, 29.9\% of the respondents had incomes that ranged from RM501 to 1000, and only $26.8 \%$ had incomes within the same range.

Table 3.6. Range of income before and after joining AIM

\begin{tabular}{lcccc}
\hline \multicolumn{2}{l}{ Ranges of Income Before and After Joining AIM } & \multicolumn{3}{c}{ After } \\
\cline { 2 - 5 } Ranges of Income & Frequency & $\begin{array}{c}\text { Percentage } \\
(\%)\end{array}$ & Frequency & $\begin{array}{c}\text { Percentage } \\
(\%)\end{array}$ \\
\hline$<$ RM 500 & 43 & 11.2 & 28 & 7.3 \\
\hline 501 to 1000 & 115 & 29.9 & 103 & 26.8 \\
\hline 1001 to 2000 & 99 & 25.8 & 105 & 27.3 \\
\hline 2001 to 3000 & 94 & 24.5 & 113 & 29.4 \\
\hline 3001 to 4000 & 17 & 4.4 & 19 & 4.9 \\
\hline$>4001$ & 16 & 4.2 & 16 & 4.2 \\
\hline Total & 384 & 100 & 384 & 100 \\
\hline
\end{tabular}

Source: Primary Data from Survey 
Before joining AIM, 25.8\% of the respondents earned RM1001 to 2000, and $27.3 \%$ of the respondents had the same range of income after joining AIM. Moreover, $24.5 \%$ of the respondents earned RM2001 to 3000 before joining AIM. The percentage of respondents who had the same range of income increased to $29.4 \%$ after joining AIM. Moreover, $4.4 \%$ and $4.9 \%$ of the respondents had an income ranging from RM3001 to 4000 before and after joining AIM, respectively. Finally, $4.2 \%$ of the respondents earned approximately RM4001 before and after joining AIM.

\subsection{Sources of household income before and after joining AIM}

Table 3.7 and Figure 3.1 show the different sources of income of the respondents before and after they joined AIM. Before joining AIM, 82.32\% of the respondents considered their spouse as the source of income, whereas $65.21 \%$ of the respondents obtained income from selfprojects after joining AIM.

Table 3.7. Sources of household income before and after of joining AIM

\begin{tabular}{lcccc}
\hline \multirow{2}{*}{ Sources of Household Income Before and After Joining AIM } & \multicolumn{3}{c}{ After } \\
\cline { 2 - 5 } & \multicolumn{2}{c}{ Before } & \multicolumn{3}{c}{$\begin{array}{c}\text { Average } \\
\text { Income }\end{array}$} & \multirow{2}{*}{$(\%)$} & $\begin{array}{c}\text { Average } \\
\text { Income }\end{array}$ & $(\%)$ \\
\hline Income from AIM projects & 28.1 & 5.44 & 1151.59 & 65.21 \\
\hline Income from spouse & 424.89 & 82.32 & 520.88 & 29.5 \\
\hline Income from fixed assets & 12.63 & 2.45 & 21.35 & 1.21 \\
\hline Income from children & 21.9 & 4.24 & 31.06 & 1.76 \\
\hline Income from pension & 9.8 & 1.9 & 9.84 & 0.56 \\
\hline Income from other sources & 18.82 & 3.65 & 31.12 & 1.76 \\
\hline Total Income & 516.15 & 100 & 1765.86 & 100 \\
\hline $\begin{array}{l}\text { Changes of income from } \\
\text { (Increased) }\end{array}$ & AIM project & \multicolumn{3}{c}{$59.77 \%$} \\
\hline
\end{tabular}

Source: Primary Data from Survey

\section{Sources of Income of the Households}

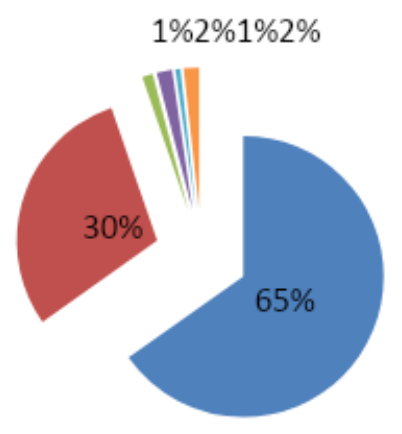

\footnotetext{
Income from AIM projects

Income from Spouse Income from Fixed

Assets

Income from children

Income from pension Income from other sources
}

Figure 3.1. Distribution of sources of household income Source: Primary Data from Survey 
The income from investments through the AIM loan increased dramatically to $59.77 \%$. Therefore, the access to credit significantly contributed to the total household income of AIM borrowers.

\subsection{Control of Money Flow in the Family}

Table 3.8 presents the distribution of the control of money flow in the family. Most decisions on the control of money were made by the borrowers and their husbands. Only $40.9 \%$ of the respondents made the decision on the control of money alone. Furthermore, only $1.0 \%$ of the respondents decided on money flow after discussing with all members of the household.

Table 3.8. Control of money in the family

\begin{tabular}{lcc}
\hline Control of Money in the Family & & \\
\hline Item & Frequency & Percentage $(\%)$ \\
\hline Husband & 23 & 6.0 \\
\hline You & 157 & 40.9 \\
\hline You and spouse & 200 & 52.1 \\
\hline Your children & 2 & .5 \\
\hline Your parents & 2 & .5 \\
\hline Total & 384 & 100.0 \\
\hline
\end{tabular}

Source: Primary Data from Survey

\subsection{Control of Capital from AIM in the Self-business Project}

Table 3.9 shows the distribution of the control of capital from AIM in the self-business project. The study found that most household decisions concerning the control of money were made by the borrowers and their husbands. Only $46.4 \%$ of the respondents decided on the capital alone. Furthermore, $0.08 \%$ of the respondents consulted with all members of the household.

Table 3.9. Control of Capital from AIM in the Self-business Project

\begin{tabular}{lcc}
\hline Control of Capital from AIM in the Self-business Project & \\
\hline & Frequency & Percentage (\%) \\
\hline Husband & 42 & 10.9 \\
\hline You & 178 & 46.4 \\
\hline You and spouse & 161 & 41.9 \\
\hline Your parents & 1 & .3 \\
\hline Others & 2 & .5 \\
\hline Total & 384 & 100.0 \\
\hline
\end{tabular}

Source: Primary Data from Survey

\subsection{Respondent Status on Economic Empowerment}

Table 3.10 shows the status of the economic empowerment of the respondents after joining AIM. The survey data were categorized based on the Observation Scales (Strongly disagree $=1$, Disagree $=2$, No change $=3$, Agree $=4$, and Strongly Agree=5). Concerning decisions on how to spend money, $68.92 \%$ of the respondents said their rights increased after joining 
AIM, whereas $8.85 \%$ said it decreased. The average comment of respondent status based on the survey data is 3.42 . For decisions about purchasing large household items, such as furniture, $65.78 \%$ of the respondents said their rights increased after joining AIM, and $14.06 \%$ of the respondents said it decreased. The average comment of respondent status from the survey data is 3.55 .

Table 3.10. Respondent status on economic empowerment

\begin{tabular}{|c|c|c|c|c|c|c|c|c|c|}
\hline \multicolumn{10}{|c|}{ Economic Empowerment Indicators } \\
\hline \multirow[t]{2}{*}{ Issues } & \multicolumn{5}{|c|}{ Observation Scale } & \multirow{2}{*}{$\begin{array}{l}\text { Average } \\
\text { Value } \\
\text { of Scale }\end{array}$} & \multirow[t]{2}{*}{ SD. } & $\begin{array}{c}\text { Proportion } \\
\text { of High }\end{array}$ & $\begin{array}{l}\text { Proportion } \\
\text { of Low }\end{array}$ \\
\hline & 1 & 2 & 3 & 4 & $5 *$ & & & 4 and $5(\%)$ & 1 and $2(\%)$ \\
\hline $\begin{array}{l}\text { Decision on how to } \\
\text { spend money }\end{array}$ & 6 & 28 & 166 & 166 & 18 & 3.42 & 0.76 & 68.92 & 8.85 \\
\hline $\begin{array}{l}\text { Decision on } \\
\text { purchasing large } \\
\text { household items, like } \\
\text { furniture }\end{array}$ & 4 & 50 & 135 & 120 & 75 & 3.55 & 0.98 & 65.78 & 14.06 \\
\hline $\begin{array}{l}\text { Decision on buying } \\
\text { gifts for social } \\
\text { functions }\end{array}$ & 5 & 14 & 65 & 266 & 34 & 3.94 & 0.52 & 78.13 & 4.95 \\
\hline
\end{tabular}

Source: Primary Data from Survey

In terms of decisions on buying gifts for social functions, $78.13 \%$ of the respondents said their rights increased after joining AIM. By contrast, $4.95 \%$ of the respondents said it decreased. The average value of respondent status from the survey data was 3.94.

\subsection{Economic Empowerment Level}

Table 3.11 and Figure 3.2 show the level of economic empowerment of the AIM borrowers. Their decision-making power in buying gifts for social functions is at $73.44 \%$, which indicated above the medium level of development based on the index values. Moreover, their decision-making power in purchasing large household items, such as furniture, is $63.8 \%$. Concerning decisions on how to spend money, the lowest value at $60.55 \%$ denoted a medium level of development based on the index values.

Table 3.17. Economic empowerment of respondents

\begin{tabular}{lcccc}
\hline Particulars & \multicolumn{4}{c}{ Economic Empowerment } \\
\cline { 2 - 5 } & $\begin{array}{c}\text { Decision on } \\
\text { Mow to Spend }\end{array}$ & $\begin{array}{c}\text { Decision on Purchasing } \\
\text { Large Household Items } \\
\text { (e.g., furniture) }\end{array}$ & $\begin{array}{c}\text { Decision on } \\
\text { Buying Gifts } \\
\text { for Social } \\
\text { Functions }\end{array}$ & $\begin{array}{c}\text { Overall EE } \\
\text { Index Value }\end{array}$ \\
\hline Total Index value & 232.5 & 245 & 282 & 253.17 \\
\hline $\begin{array}{l}\text { Average Index } \\
\text { Value }\end{array}$ & 0.605 & 0.638 & 0.734 & 0.659 \\
\hline $\begin{array}{l}\text { Average Index } \\
\text { Value }(\%)\end{array}$ & 60.55 & 63.8 & 73.44 & 65.93 \\
\hline
\end{tabular}

Source: Primary Data from Survey 


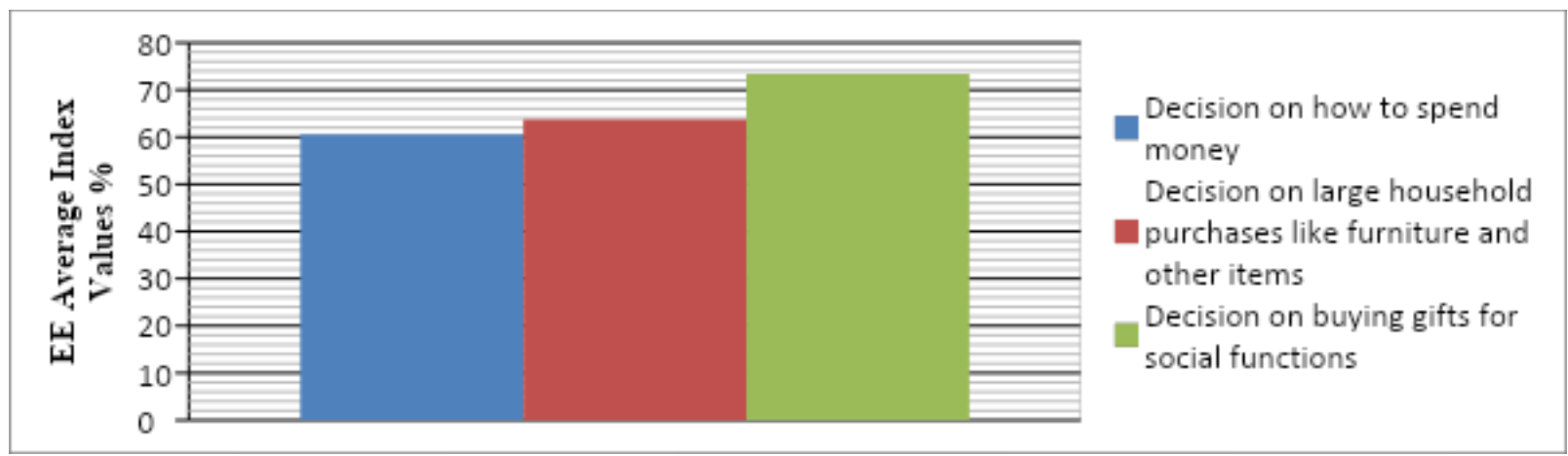

Figure 3.2. Economic empowerment of AIM Borrowers

Source: Primary Data from Survey

The overall economic empowerment index values showed $65.93 \%$ improvement. Based on the overall economic empowerment index values, AIM borrowers improved their decisionmaking power regarding economic participation with access to credit, but this improvement is not considered as remarkable progress

\section{Conclusion}

The study aims to investigate the effects of AIM microcredit on the empowerment of women borrowers in the east coast region of Malaysia. The empirical analysis revealed that AIM microcredit influenced the level of empowerment of the borrowers after they joined AIM. In the current study, credit was observed to contribute to the increase of the average monthly household income of respondents over the last five years. Microcredit has provided enough scope to operate IGAs. Five years before joining AIM, only $61.7 \%$ of the respondents were self-employed or engaged in business. After joining AIM, 77.6\% of the respondents became self-employed. Before joining AIM, 23.4\% of the respondents were housewives, but the housewives comprised only $21.3 \%$ after the respondents joined AIM. Moreover, the average monthly income of the respondents five years before the study was RM516.15, whereas the average monthly income of the respondents at the time of the study was RM1765.86. Furthermore, the household income of the respondents increased by $242.12 \%$ in five years. Decisions on obtaining a loan from AIM, family issues, and control of money was done in consultation with their husbands. Most respondents $83.6 \%$ of reported the good health condition of their families, and about $10.9 \%$ of the respondents said their families were in very good health condition. The score of women empowerment indexes was based on the economic empowerment of the AIM borrowers after joining AIM credit. The values for the overall economic empowerment showed $65.93 \%$ of improvement. Based on the index values of the overall EE, the AIM borrowers improved their rights to decide regarding economic participation, but this rate is not remarkable. Finally, the findings recommend AIM borrowers should improve on their right to decide concerning economic issues, this result is not considered remarkable progress.

\section{Acknowledgement}

The authors are thankful to the CRIL, UNISEL for allowing of using of KPT FRGS Grant: FRGS/1/2018/SS01/UNISEL/02/ entitled "FORMULATION OF MICROFINANCE 
INSTITUTIONS SUSTAINABILITY INDEX (MISI) IN MALAYSIA” for financial support to carry out this research to be published.

\section{References}

9th.Malaysia.Plan. (2006). The 9th Malaysia plan: 2006-2010. Unit Economic Planing, Putra Jaya, Malaysia: Prime Minister's Department.

Ahmed, F., Siwar, C., \& Idris, N. A. H. (2011a). Role of microcredit programme to the socioeconomic development and poverty: Alleviation among rural women in Bangladesh. Journal of Applied Sciences Research, 7(7), 1117-1121.

Ahmed, F., Siwar, C., \& Idris, N. A. H. (2011b). The status of women: Some data in Bangladesh. Journal of Applied Sciences Research, 7(6), 805-809.

Ahmed, F., Siwar, C., \& Idris, N. A. H. (2011c). Sustainable livelihood amongst rural women through microcredit programme in Bangladesh. Australian Journal of Basic and Applied Sciences, 5(7), 116-120.

Ahmed, F., Siwar, C., \& Idris, N. A. H. (2011d). Women's participation in microcredit programme: Some evidence in Bangladesh. Australian Journal of Basic and Applied Sciences, 5(7), 106-115.

Ahmed, F., Siwar, C., Idris, N. A. H., \& Begum, R. A. (2011). Impact of Grameen bank microcrdit programme on changing livelihood status of the rural women in Panchagarh District of Bangladesh. American Journal of Applied Sciences, 8(10), 973-978.

Ahmed, F., Siwar, C., Idris, N. A. H., \& Mia, M. S. (2011). Role of microcredit in reducing vulnerability of the rural women: Evidence from Panchgarh district of Bangladesh. World Applied Sciences Journal, 15(9), 1325-1333.

Angeles, L. C., \& Hill, K. (2009). The gender dimension of the agrarian transition: Women, men and livelihood diversification in two peri-urban farming communities in the Philippines. Gender, Place and Culture, 16(5), 609-629.

APEC. (2005). The Need and Availability of Micro Finance Service for the Micro Enterprise:Bringing multi-level Good Practices into Local Context.

Basher, M. (2007). Empowerment of microcredit participants and its spillover effects: evidence from the Grameen Bank of Bangladesh. The Journal of Developing Areas, 40(2), 173183.

Bhole, B., \& Ogden, S. (2010). Group lending and individual lending with strategic default. Journal of Development Economics, 91(2), 348-363. doi:10.1016/j.jdeveco.2009.06.004.

Bhuiya, A., \& Chowdhury, M. (2002). Beneficial effects of a woman-focused development programme on child survival: evidence from rural Bangladesh. Social Science \& Medicine, 55(9), 1553-1560. doi:10.1016/S0277-9536(01)00287-8.

Bhuiyan, A. B., Siwar, C., Ismail, A. G., \& Hossain, T. B. (2012). Microcredit Impact on Children's Education and Women Empowerment: A Review Experience of Grameen Bank Microfinance Schemes in Bangladesh. Research Journal of Applied Sciences, 5.

Bhuiyan, A. B., Siwar, C., Ismail, A. G., \& Talib, B. (2011). Islamic Microcredit is the way of alternative approach for eradicating poverty in Bangladesh: A review of Islami bank Microcredit scheme. Australian Journal of Basic and Applied Sciences, 5(5), 221-230.

Bose, M. L., Ahmad, A., \& Hossain, M. (2009). The role of gender in economic activities with special reference to women's participation and empowerment in rural Bangladesh. Gender, Technology and Development, 13(1), 69-102.

Chan, S. H., \& Ghani, M. A. (2011). The impact of microloans in vulnerable remote areas: Evidence from Malaysia. Asia Pacific Business Review, 17(1), 45-66. 
D'Espallier, B., Guérin, I., \& Mersland, R. (2011). Women and Repayment in Microfinance: A Global Analysis. [doi: 10.1016/j.worlddev.2010.10.008]. World Development, 39(5), 758-772.

Esnard-Flavius, T., \& Aziz, Z. (2011). Microcredit, microenterprises and social welfare of the rural poor in North-Eastern Trinidad: An evaluation of "Hope". Asian Academy of Management Journal, 16(1), 95-118.

Gibbons, D. S., \& Kasim, S. (1990). Banking on the rural poor in Peninsular Malaysia: Center for Policy Research, Universiti Sains Malaysia.

Haile, H. B., Bock, B., \& Folmer, H. (2012). Microfinance and female empowerment: Do institutions matter? Women's Studies International Forum.

Hazarika, G., \& Sarangi, S. (2008). Household Access to Microcredit and Child Work in Rural Malawi. [doi: DOI: 10.1016/j.worlddev.2007.05.008]. World Development, 36(5), 843859.

Hearn, B., Piesse, J., \& Strange, R. (2011). The role of the stock market in the provision of Islamic development finance: Evidence from Sudan. Emerging Markets Review, 12(4), 338-353.

Hermes, N., Lensink, R., \& Meesters, A. (2011). Outreach and Efficiency of Microfinance Institutions. World Development, 39(6), 938-948.

Holland, T., \& Wang, L. (2001). Avoiding the perils and fulfilling the promises of microfinance: A closer examination of the educational outcomes of clients' children in Nicaragua. [doi: DOI: 10.1016/j.ijedudev.2010.07.002]. International Journal of Educational Development, In Press, Corrected Proof.

Khandker, S. (1998). Micro Credit Programme Evaluation: A Critical Review1. IDS bulletin, 29(4), 11-20.

Khandker, S. R. (2005). Micro-Finance and Poverty Evidence Using Panel Data from Bangladesh. The World Bank Economic Review.

Khandker, S. R., \& Chowdbury, O. H. (1996). Targeted Credit Programme and Rural Poverty in Bangladesh. Washington, D.C.:: World Bank

M.Salma. (2004). A Comparative Case Study on Outreach and Impact of Ikhtiar Loan Scheme and Special Program for Hardcore Poor in Seberang Perai Pulau Pinang. . University Science Malaysia.

Mamun, A. A., Wahab, S. A., Hossain, S., \& Malarvizhi, C. (2011). Impact of Amanah Ikhtiar Malaysia's Microcredit Schemes on Hardcore Poor Households Quality of Life.

Mason, K. O., \& Smith, H. L. (2003). Women's empowerment and social context: results from five Asian Countries. Gender and Development Group, World Bank, Washington, DC.

McKernan, S. M. (2002). The Impact of Microcredit Programs on Self-Employment Profits: Do Noncredit Program Aspects Matter? Review of Economics and Statistics, 84(1), 93 115.

Mirghani, M., Mohammed, M., Bhuiyan, A. B., \& Siwar, C. (2011). Islamic microcredit and poverty alleviation in the Muslim World: Prospects and challenges. Australian Journal of Basic and Applied Sciences, 5(9), 620-626.

Misturelli, F., \& Heffernan, C. (2010). The concept of poverty: A synchronic perspective. Progress in Development Studies, 10(1), 35-58.

Moniruzzaman, M. (2011). Group management and empowerment: Lessons from development NGOs in Bangladesh. Journal of South Asian Development, 6(1), 67-91.

Nawai, N. B., \& Bashir, M. S. (2009). Evaluation of micro credit program for poverty alleviation: A case of Amanah Ikhtiar Malaysia (AIM).

Perry, D. (2002). Microcredit and women moneylenders: The shifting terrain of credit in Rural Senegal. Human Organization, 61(1), 30-40. 
Pitt, M. M., Khandker, S. R., Chowdhury, O. H., \& Millimet, D. L. (2003). Credit programs for the poor and the health status of children in rural bangladesh*. International Economic Review, 44(1), 87-118.

Rahman, A. (1999). Micro-credit initiatives for equitable and sustainable development: Who pays? [doi: 10.1016/S0305-750X(98)00105-3]. World Development, 27(1), 67-82.

Rowlands, J. (1997). Questioning empowerment: Working with women in Honduras: Oxfam Publications.

Serrona, K. R., \& Yu, J.-s. (2009). Finding urban waste management solutions and policies: Waste-to-energy development and livelihood support system in Payatas, Metro Manila, Philippines. [doi: 10.1016/S1001-0742(09)60033-4]. Journal of Environmental Sciences, 21(Supplement 1), S40-S43.

Shimamura, Y., \& Lastarria-Cornhiel, S. (2010). Credit Program Participation and Child Schooling in Rural Malawi. [doi: DOI: 10.1016/j.worlddev.2009.11.005]. World Development, 38(4), 567-580.

Siti-Nabiha, A. K., \& Siti-Nazariah, A. Z. (2011). Evaluating social performance: A case study of a microfinance institution in Malaysia. International Journal of Management and Enterprise Development, 10(4), 271-290.

Stromquist, N. P. (2002). Education as a means for empowering women. Rethinking empowerment: Gender and development in a global/local world, 22-38.

Vargas, \& MarÍa, C. (2002). Women in Sustainable Development: Empowerment through Partnerships for Healthy Living. [doi: DOI: 10.1016/S0305-750X(02)00058-X]. World Development, 30(9), 1539-1560.

Varghese, T. (2011). Women Empowerment in Oman: A study based on Women Empowerment Index. Far East Journal of Psychology and Business, 2(2), 37-49.

Wallerstein, N. (1992). Powerlessness, empowerment, and health: implications for health promotion programs. American journal of health promotion, 6(3), 197-205.

Zahra, S. A., Gedajlovic, E., Neubaum, D. O., \& Shulman, J. M. (2009). A typology of social entrepreneurs: Motives, search processes and ethical challenges. [doi: DOI: 10.1016/j.jbusvent.2008.04.007]. Journal of Business Venturing, 24(5), 519-532.

Zaman, H. (1999). Assessing the poverty and vulnerability impact of micro-credit in Bangladesh: A case study of BRAC. Washington D.C, World Bank. 